\title{
A Murder of Crows: Culling Corvids in Northern Cyprus
}

\section{Khalil Avi Betz Heinemann ${ }^{1}$ (D) $\cdot$ Meryem Betmezoğlu $^{2} \cdot$ Mahmut Cerkez Ergoren $^{3,4}$ (D) $\cdot$ Wayne J. Fuller ${ }^{2}$}

Published online: 15 May 2020

(C) The Author(s) 2020

Keywords Corvids $\cdot$ Target species' social structure $\cdot$ Population densities $\cdot$ Population control $\cdot$ Environmental management strategies $\cdot$ Culling $\cdot$ Breeding strategies $\cdot$ Vermin $\cdot$ Adaptation $\cdot$ TRNC

\section{Introduction}

Culling, the killing of non-human animals, is practiced worldwide as a form of population control and environmental management. In tandem with other practices, culling is expected to deliver ecosystems valued by those performing such tasks. Examining its efficacy is crucial in maintaining a cull's legitimacy and ensuring its ecological value.

Our study explores the efficacy of corvid culling in the Turkish Republic of Northern Cyprus (TRNC) and how corvid social structure can nullify its effectiveness as a form of population control. On average around 15,000 corvids are culled annually in Northern Cyprus (Graph 1) on the grounds that they cause harm to game animal populations such as European hare (Lepus cyprius) and chukar (Alectoris chukar), which are valued hunters' quarry. However, despite the number of corvids culled every year, their populations remain

Murder: Collective noun for a group of crows.

Khalil Avi Betz Heinemann

avikhalil@protonmail.com

Meryem Betmezoğlu

meryembetmezoglucyrus@gmail.com

Mahmut Cerkez Ergoren

mahmutcerkez.ergoren@neu.edu.tr

Wayne J. Fuller

wayne.fuller@neu.edu.tr

1 Kent Interdisciplinary Centre for Spatial Studies, University of Kent, Canterbury, England

2 Faculty of Veterinary Medicine, Near East University, Nicosia, Northern Cyprus

3 Department of Medical Biology, Faculty of Medicine, Near East University, Nicosia, Northern Cyprus

4 DESAM Institute, Near East University, Nicosia, Northern Cyprus high, and the populations of valued species meant to be protected through culling continue to diminish.

Lazenby et al.'s (2014) study on the culling of feral cats in Tasmania provides a clear insight into why culling may not deliver the expected results. The feral cats' culling, contrary to delivering population reduction, had exacerbated the problem because the social life of the target animals had not been taken into consideration. As a result of culling, copulations and consequently population increased when relieved of the social and competitive checks on reproduction that the culled individuals had formerly provided.

Turning to our case study in Northern Cyprus, Hooded crows (Corvux cornix) and Eurasian magpies (Pica pica) are the corvid species culled. Corvids are well known for their intelligence and behavioural plasticity (Baglione and Canestrari 2016; Clayton and Emery 2007). Such traits can vary according to location and specific population dynamics, with different breeding strategies developing over time (Clayton and Emery 2007). Cooperative, colonial, and pair breeding have been noted amongst Hooded crows and Eurasian magpies in Europe (Loman 1980) and are best estimated to exhibit a population sex-ratio of 1:1 (Fisher 1999).

Due to biological constraints of sexual rather than asexual reproduction, the reproductive success of corvid populations is more dependent on females than males, especially in cooperative and colonial breeding systems. Therefore, we hypothesized that culling is less effective than anticipated if males are disproportionately and inadvertently targeted.

During this research, we worked with members of the TRNC Hunting Federation, who collect the heads of culled corvids in order to receive state subsidies. Using these readily available samples and submitting them to genetic analysis, it was possible to obtain a sex ratio of these culled individuals and thus to test whether our hypothesis was correct.

Simultaneously, we researched the historical and ethnographic context of corvid culling in Northern Cyprus to identify whether the rationale for culling was robust. In the case of humans, killing another human is not by default illegitimate, 
Graph 1 Number of corvids culled per year in Northern Cyprus

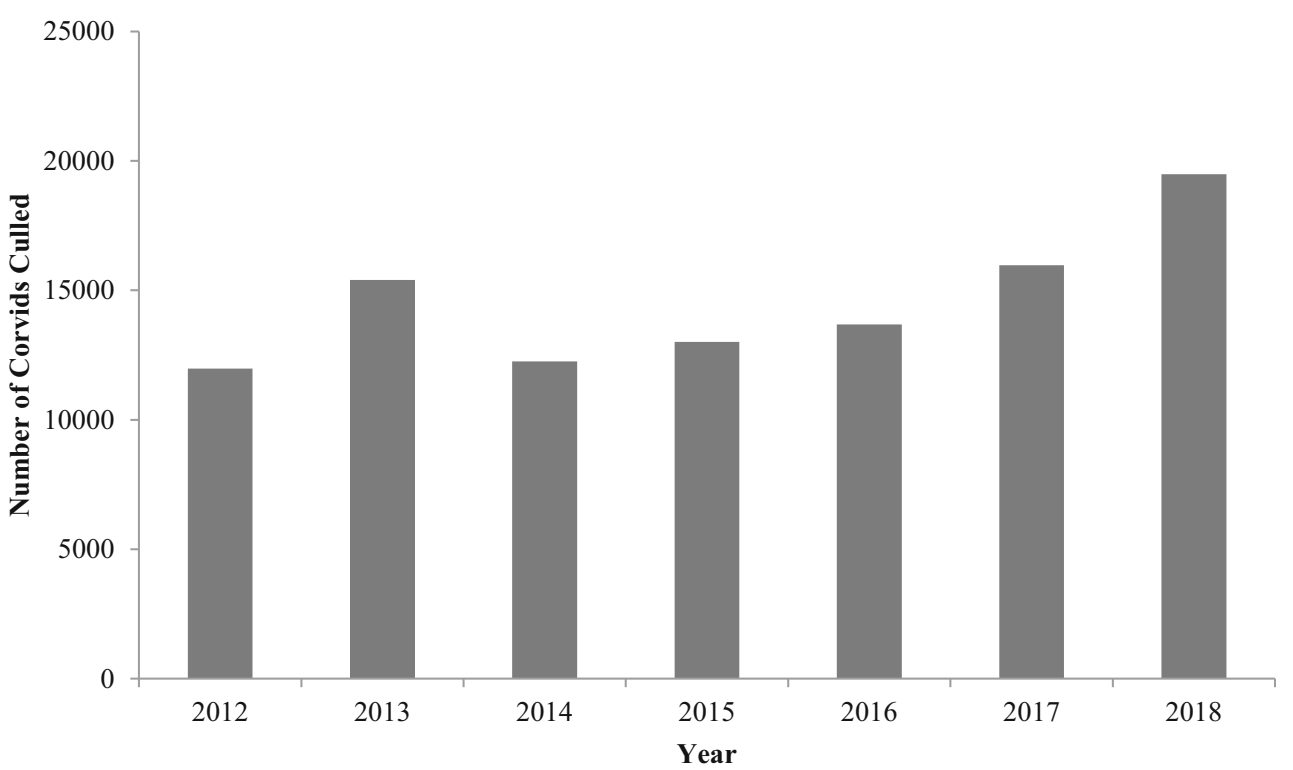

but if it falls outside of a robust rationale, it is. In such cases, it is called murder. While corvids are not humans, the legitimacy for killing as culling also rests on a rationale: population control. We argue the legitimacy of culling as population control rests on its effectiveness. Without this, it is illegitimate.

\section{Materials and Methods}

\section{Participant Observation and Archival Review}

Participant observation (Bernard 2011: 256-290) during three culling seasons (2014-16) enabled data collection on the conduct of the cull. We took handwritten notes, photos and video clips to document the conversations and activities that constituted culling. We also conducted participant observation at the offices of the TRNC Hunting Federation during daily work activities, including attending hunting club meetings and the processing of corvid heads, and compared our findings with those we had gathered through participant observation across the rest of the year when game animals were hunted, again using documentation of practices and conversations.

We conducted semi-structured interviews with research participants and obtained life histories (Angrosino 2007: 3344) to respectively follow up on questions that had arisen during participant observation and to contextualize our observations. Potential participants were identified through snowball sampling. From these, 37 participants were selected from a variety of locations and a range of socioeconomic statuses and ages using purposive sampling. These included people from across the five administrative regions of Northern Cyprus: farmers, factory workers, pensioners, estate-agents, lawyers, students, care-workers, advertising executives, retailers, politicians, and waste collectors, ages 18-74 (average
48); 36 men and 1 woman, reflecting the national composition of the hunting community.

We also conducted an archival review of the TRNC Hunting Federation's records, as well as those of the Interior Ministry and the National Archives in order to gather quantitative data on the number of corvid heads submitted by hunters in return for subsidies, how many people were specially licensed to perform the cull, as well as the historical and legal context of contemporary practices. Prior informed consent (Alexiades 2002) was requested and received from all participants included in this study.

\section{Genetic Sampling, Sexing, and DNA Extraction}

A total of 119 Hooded crows (Corvux cornix) and Eurasian magpies (Pica pica) heads were donated by the local TRNC Hunting Federation and sampled. Each head was examined, morphometrics taken and sexed using genetic markers. The study started with 50 crows (28 Hooded crows; 22 Eurasian magpies) from the 2016 cull, followed by an additional 69 Hooded crow samples in 2018.

Crow tongue biopsies were preserved in $90 \%$ alcohol. In order to facilitate DNA extraction, each biopsy was divided into smaller pieces $\left(\approx 1 \mathrm{~mm}^{3}\right)$. DNA extraction was performed using Invitrogen DNA Life DNA isolation kits in accordance with the manufacturer's guidelines. Following the extraction process, all PCR reactions were performed using an eppendorf mastercycler gradient PCR thermal cycler. Two primer sets were used for the amplification of the CHD gene; P2 $\left(5^{\prime}-\right.$ TCT GCA TCG CTA ATT CCT TT -3') and P8 (5' - CTC CCA AGG ATG ATC AGR AYY TG -3'). These were used to determine the sex of the birds using genetic markers (Griffiths et al. 1998). PCR reactions were carried out in a total volume of $25 \mu \mathrm{L}$ with $12.5 \mu \mathrm{L}$ Thermo PCR Master 


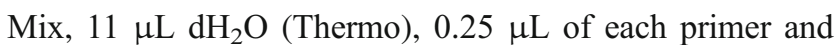
$10 \mathrm{ng}$ of Genomic DNA. An initial denaturation step at $94{ }^{\circ} \mathrm{C}$ for $2 \mathrm{~min} ; 40$ cycles of denaturation at $94{ }^{\circ} \mathrm{C}$ for $45 \mathrm{~s}$, annealing (for $45 \mathrm{~s}$ ) at $48^{\circ} \mathrm{C}$ and extension at $72{ }^{\circ} \mathrm{C}$ for $30 \mathrm{~s}$ and $72{ }^{\circ} \mathrm{C}$ for $5 \mathrm{~min}$ completed the program. The PCR results were visualized on a $2 \%$ agarose gel with ethidium bromide. Bio-Imaging Systems MiniBIS Pro was used for gel imaging.

\section{Results}

\section{The Conduct of Corvid Culling in Northern Cyprus}

Between 2012 and 2018 an average of 14,539 corvids were killed during the annual 'Crow Hunt' (Graph 1). Held on weekends from late May to early June, it is conducted by specially licensed hunters from hunting clubs spread across the country. These clubs cumulatively constitute the TRNC Hunting Federation - the organization that represents hunters and manages hunting, which incorporates this annual cull on behalf of the TRNC Interior Ministry. The head of each culled corvid is removed from its carcass and exchanged for a state subsidy in the form of shotgun cartridges. These are ostensibly a replacement for those used to kill the individual birds, set at 4 cartridges per head in 2013.

\section{The Reasoning for Corvid Culling in Northern Cyprus}

The legal origins of culling corvids in Northern Cyprus emerged during British colonial rule in Cyprus (1878-1960). In 1911, a law pertaining to the collection of eggs of birds deemed to be harmful or overly plentiful was passed, and later in 1922 amended to include the shooting of birds. With these legal changes Cypriots, as British colonial subjects, had to provide British colonial officials with a specified number of corvid heads (approximately 25) caught through trapping and/ or other methods in order to gain a hunting license. In this way, there was no specific license required to kill corvids, just as there has not been in England until recently (Barkham 2019), but killing them enabled access to a hunting license. This law, along with many others, has been carried through into what is now the basis of the legal system in Northern Cyprus under the TRNC government.

The official narrative that justifies this law concerning culling corvids is that they prey on the eggs and young of other animals deemed to be valuable and/or vulnerable. Specifically, the premise is that these other animals (game birds and hare) require protection, as they provide the game for hunting. The official term given to this practice of culling corvids translates from Turkish as 'the struggle against harmful ones.' Amongst hunters, it is referred to as hunting but qualified to us in interviews as 'not real hunting' but rather the 'cleaning' of corvids, where cleaning is colloquially understood to be culling. The reasoning, therefore, is that an annual season every year to 'clean' corvids will reduce their populations and their associated impacts on game animals.

This belief that corvids are vermin is not confined to Northern Cyprus or British colonial law. It is held by hunters, farmers, and bird watchers and their organizations across Europe, as well as being reflected in recurrent European national policies. Many other species are also culled around the world with similar reasoning: that they are harmful in some way to the pursuits of humankind or 'the environment' and are thus vermin that should be controlled.

\section{The Technical Efficacy of Corvid Culling in Northern Cyprus}

A total of 125 corvids were sampled (22 magpies and 103 crows), from which we were able to sex a total of $102(82 \%)$ through DNA analysis, $16(73 \%)$ magpie and $86(83 \%)$ crows. Of the total sexed samples, $64 \%$ were male. Across both sampling years, $62 \%$ of the crows were found to be male, and $81 \%$ of the magpies, which were only sampled in 2016, were male. Moreover, due to inappropriate sample collection, DNA could not be extracted from $11 \%$ of samples, and sex determination could not be processed for $12 \%$ of samples due to DNA degradation. However, the total number of analyzed samples was sufficient to conclude that there is sex bias towards male corvids in the culled samples (Table 1). Specifically, where the observed number of male corvids culled (64.7\%) differs significantly from the expected proportion $(50 \%)$ when corvid sex ratios are considered in line with the Fisher 1:1 sex ratio principle (Fisher 1999). We used a single proportion test to calculate $p$-values (using Z-statistics in PAST 3.25 software package) to find that the deviation from the expected proportion is significant (at $p<0.05$ ) with $\mathrm{Z}=2.7264$ and $p=$ 0.0064021 .

\section{Discussion}

This study highlights that the social life of a species needs to be fully considered to understand the effect of a cull. The sex bias in corvid culling in Northern Cyprus revealed through

Table 1 Details of sampled Hooded crows (Corvus cornix) and Eurasian magpies (Pica pica) with their associated sex ratios. NE $=$ Failed DNA extraction; NS = Unable to Determine Sex from extracted DNA. Figures in parentheses are the related percentages

\begin{tabular}{lrlrrrr}
\hline Species & \multicolumn{1}{l}{ Total } & NE & \multicolumn{1}{l}{ NS } & Total sexed & Female & Male \\
\hline C. cornix & 103 & $7(6.8)$ & $10(9.7)$ & $86(83.5)$ & $33(38.4)$ & $53(61.6)$ \\
P. pica & 22 & $4(18.2)$ & $2(9.1)$ & $16(72.7)$ & $3(18.8)$ & $13(81.3)$ \\
Total & 125 & $11(8.8)$ & $12(9.6)$ & $102(81.6)$ & $36(35.3)$ & $66(64.7)$ \\
\hline
\end{tabular}


genetic sexing indicates that the culling method is biased towards male corvids and can, therefore, be considered inefficient. The timing of the corvid hunting season in spring at the height of the corvid breeding season (Loman 1980: 28), when females are on their nests and not such available targets, could be one reason as to why there is a sex bias in the cull. If so, this suggests that moving the timing of the culling could change this bias in favour of a more gender-balanced cull, improving the cull efficiency.

Beyond the inefficiency of overwhelmingly targeting male corvids amongst populations with breeding strategies that are more dependent on females than males, a further consideration is that non-breeding 'murders' of Hooded crows are common (ibid. 31-34). If these are being accidentally targeted, it will not considerably affect the overall reproductive success of the population.

However, our main conclusion from the research presented here relates to the overall adaptation of corvid social structure with long term culling. The reproductive success of Hooded crows is mediated by breeding density as part of a territorial system (ibid. 32). They have a, 'relatively high stability in breeding density and probably also reproductive output... [which] indicates that each population is balanced at a certain breeding density... [and] this balance is mediated by social mechanisms in a territorial system' (ibid. 31-32). In addition, corvids employ strategies to account in the face of potential population loss (ibid. 33).

The annual loss of a percentage of corvid populations through culling in Northern Cyprus thus disrupts corvids' territorially balanced breeding density, and consequently how they organize their reproductive strategies in relation to their ecosystem. The annual corvid culling has occurred for over 30 years. Spatially, Northern Cyprus is divided up among hunting clubs that collectively spread their culling across the country's territory. Thus, the overall effects of culling have been widespread. Given that corvids have a life expectancy of up to 15 years, a cross-generational shift in corvid social structure will have taken place. Therefore, corvids have continued to flourishas the effect of culling is no longer a disruption but has become an environmental condition to which corvid population densities and their socially managed territorial systems will have adapted.

We argue that corvids have adapted to culling by increasing breeding density and this adaptation has led to the maintenance of their numbers as they incorporate their annual population loss into their territorial adjustments of population density. It is unknown whether this adaptation is biologically reflected. However, a shift in corvid behaviour and social structure will have occurred in the face of periodic culling, otherwise social organization - required for biological reproduction - would have fractured, leaving corvids unable to reproduce as 'murders,' and the social knowledge and skills this provides to ensure their biological continuity.
In sum, hunters have put corvids in the position of opportunistic competition with themselves for wildlife resources as part of an entanglement of war (Dalla Bernardina 2009). However, the opportunistic intelligence and flexibility of corvids' social organization (Baglione and Canestrari 2016; Clayton and Emery 2007) does not make them the competition. Instead, it is what enables them to flourish as a species in the niche of competitive opposition offered by the social conditions of environmental management that have emerged in Northern Cyprus. This environment of competition is something explicitly stated by culling authorities, who describe and reproduce related infrastructure - create a niche - based on the idea of corvids as competitors.

\section{Conclusion}

The culling of corvids in Northern Cyprus is inefficient because it disproportionately targets males, as well as disrupting corvid social structure thus triggering higher reproductive strategies that serve to maintain corvid population densities. Consequently, we recommend strategies going "beyond the war" (Orion 2015) to control corvid populations, beginning with taking into consideration their social organization and the timing of their breeding season. Annual culling uninformed by such considerations is inevitably inefficient and cannot achieve its stated goals, potentially delegitimizing environmental management practices.

Acknowledgements We are deeply grateful to our study participants, who graciously shared their time, energy, and stories. We thank the members of staff of the TRNC Hunting Federation and the Cyprus Wildlife Research Institute for making this research possible.

Funding This study was funded by Economics and Social Science Research Council (ESRC) UK.

\section{Compliance with Ethical Standards}

Conflict of Interest The authors declare that they have no conflict of interest.

Informed Consent Prior informed consent was requested and received from all participants included in this study.

Open Access This article is licensed under a Creative Commons Attribution 4.0 International License, which permits use, sharing, adaptation, distribution and reproduction in any medium or format, as long as you give appropriate credit to the original author(s) and the source, provide a link to the Creative Commons licence, and indicate if changes were made. The images or other third party material in this article are included in the article's Creative Commons licence, unless indicated otherwise in a credit line to the material. If material is not included in the article's Creative Commons licence and your intended use is not permitted by statutory regulation or exceeds the permitted use, you will need to obtain permission directly from the copyright holder. To view a copy of this licence, visit http://creativecommons.org/licenses/by/4.0/. 


\section{References}

Alexiades, M., 2002. Prior Informed Consent: the politics of cross cultural exchange., in: D. Biodiversity and Traditional Knowledge: Equitable Partnerships in Practice. Easrthscan, London, UK.

Angrosino, M.V. (Ed.), 2007. Doing cultural anthropology: projects for ethnographic data collection, 2nd ed. ed. Waveland Press, Long Grove, Ill.

Baglione, V., Canestrari, D., 2016. Carrion crows: Family living and helping in a flexible social system, in: Koenig, W.D., Dickinson, J.L. (Eds.), Cooperative Breeding in Vertebrates. Cambridge University Press, Cambridge, pp. 97-114. https://doi.org/10.1017/ CBO9781107338357.007

Barkham, P., 2019. Woodpigeons and crows can no longer be freely killed in England. The Guardian.

Bernard, H.R., 2011. Research methods in anthropology: qualitative and quantitative approaches, 5th ed. ed. AltaMira Press, Lanham, Md.

Clayton, N.S., Emery, N.J., 2007. The Social Life of Corvids. Curr. Biol. 17, R652-R656. https://doi.org/10.1016/j.cub.2007.05.070

Dalla Bernardina, S., 2009. Le gibier de l'apocalypse: Chasse et théorie du complot. Ethnol. Fr. 39, 89. https://doi.org/10.3917/ethn.091. 0089
Fisher, R.A., 1999. The genetical theory of natural selection: by R.A. Fisher ; edited with a foreword and notes by J.H. Bennett, A Complete Variorum ed. ed. Oxford University Press, Oxford.

Griffiths, R., Double, M.C., Orr, K., Dawson, R.J.G., 1998. A DNA Test to Sex Most Birds. Mol. Ecol. 7, 1071-1075. https://doi.org/10. 1046/j.1365-294x.1998.00389.x

Lazenby, B.T., Mooney, N.J., Dickman, C.R., 2014. Effects of LowLevel Culling of Feral Cats in Open Populations: a Case Study from the Forests of Southern Tasmania. Wildl. Res. 41, 407. https://doi. org/10.1071/WR14030

Loman, J., 1980. Reproduction in a Population of the Hooded Crow Corvus Cornix. Ecography 3, 26-35. https://doi.org/10.1111/j. 1600-0587.1980.tb00705.x

Orion, T., 2015. Beyond the War on Invasive Species: a Permaculture Approach to Ecosystem Restoration. Chelsea Green Publishing, White River Junction, Vermont.

Publisher's Note Springer Nature remains neutral with regard to jurisdictional claims in published maps and institutional affiliations. 